\title{
PENGEMBANGAN MEDIA PEMBELAJARAN CD TUTORIAL INTERAKTIF PADA MATA PELAJARAN SIMULASI DIGITAL
}

\author{
Baiq Hartina Maisiswati ${ }^{1}$, Kholida Ismatullah ${ }^{2}$, Muhammad Zamroni Uska ${ }^{3}$, \\ ${ }^{1,2,3}$ Program Studi Pendidikan Informatika, \\ Fakultas Matematika dan Ilmu Pengetahuan Alam, Universitas Hamzanwadi \\ Email: baiqtitin1305@gmail.com ${ }^{1}$, KholidaIsmatullah@ gmail.com ${ }^{2}$, \\ zamroniuska@gmail.com ${ }^{3}$
}

\begin{abstract}
Abstrak
Tujuan penelitian ini yaitu (1) untuk mengetahui pengmbangan media pembelajaran CD tutorial pada mata pelajaran simulasi digital pada kelas X di SMKN 1 Sakra; (2) untuk mengetahui kelayakan ahli media dan ahli materi terhadap produk media pembelajaran CD tutorial; (3) untuk mengetahui respon siswa terhadap pengembangan media pembelajaran $\mathrm{CD}$ tutorial pada mata pelajaran simulasi digital pada kelas X di SMKN 1 Sakra. Jenis penelitian ini menggunakan metode pengembangan R\&D (Reseach and Development). Subyek penelitian ini adalah kelas X TKJ sebanyak 20 orang siswa. Pengumpulan data berupa wawancara, angket, dan observasi.Teknik analisis data menggunakan data kuantitatif dan kualitatif. Hasil penelitian menunjukan bahwa media pembelajaran CD tutorial yang dikembangkan dari validasi ahli media untuk media $\mathrm{CD}$ tutorial dinyatakan sangat layak karena memiliki persentase rata-rata sebesar $92 \%$, sementara itu untuk validasi ahli materi memiliki persentase rata-rata sebesar $91 \%$, dan untuk respon siswa dikatakan sangat baik karna memiliki persentase rata-rata sebesar $90 \%$, sehingga dapat dikatakan media pembelajaran CD Tutorial efektif digunakan dalam proses pembelajaran di SMKN 1 Sakra.
\end{abstract}

Kata Kunci: Media Pembelajaran, CD Tutorial, Simulasi Digital.

\begin{abstract}
The purpose of this study is (1) to determine the development of instructional CD learning media on digital simulation subjects in class X at 1 Sakra Vocational High School; (2) to find out the feasibility of media experts and material experts on learning CD tutorial media products; (3) to find out the students' response to the development of tutorial CD learning media on digital simulation subjects in class $X$ at Sakra Vocational High School 1. This type of research uses $R \& D$ (Reseach and Development) development methods. The subjects of this study were class X TKJ as many as 20 students. Data collection in the form of interviews, questionnaires, and observations. Data analysis techniques use quantitative and qualitative data. The results showed that the learning media tutorial $C D$ developed was very valid for use in the learning process. From the media expert validation for the media, the tutorial CD was declared to be very feasible because it had an average percentage of $92 \%$, while the validation of material experts had an average percentage of $91 \%$, and for students' responses it was said to be very good because it had an average percentage of $90 \%$, so that it can be said that the Tutorial CD learning media is effectively used in the learning process at SMK 1 Sakra.
\end{abstract}

Keywords: Learning Media, Tutorial CD, Digital Simulation.

\section{PENDAHULUAN}

Pendidikan merupakan usaha sadar dan terencana untuk mewujudkan suasana belajar dan proses pembelajaran agar siswa secara aktif mengembangkan potensi dirinya untuk memiliki pengetahuan yang baru seperti, contoh: siswa mampu lebih aktif dalam mengikuti proses pembelajaran dengan menerapkan media yang menarik dan membuat siswa tidak merasa bosan. Dimana seorang guru juga perlu lebih kreatif dan inovatif dalam 
mengembangkan dan menyampaikan pelajaran yang mampu membuat siswa lebih aktif. Oleh karena itu, peranan seorang guru harus mampu menyediakan media atau alat bantu lainnya.

Menurut Rusman (2012: 50) peran guru yang dimaksud disini adalah berkaitan dengan peran guru dalam proses pembelajaran. Guru merupakan faktor penentu yang sangat dominan dalam pendidikan pada umumnya, karena guru memegang peranan dalam proses pembelajaran, dimana proses pembelajaran merupakan inti dari proses pendidikan secara keseluruhan. Peranan guru meliputi banyak hal, yaitu guru dapat berperan sebagai pengajar, pemimpin kelas, pembimbing, pengatur lingkungan belajar, perencana pembelajaran, supervisor, mutivator dan sebagai evaluator.

Selain itu lembaga pendidikan seperti sekolah juga memerlukan media pembelajaran digunakan untuk menarik perhatian dan membuat siswa aktif dalam proses pembelajaran, salah satunya adalah menggunakan media pembelajaran CD Tutorial interaktif. Di mana media pembelajaran CD tutorial interaktif adalah salah satu media pembelajaran berbasis elektronik. Sehingga kegiatan belajar di tingkat sekolah harus lebih menarik dan menyenangkan, selain itu siswa dapat mudah menerima pembelajaran yang disampaikan guru. Media yang sudah tersedia kadang kurang memberikan dampak yang positif bagi pembelajaran di dalam kelas. Hal ini diakibatkan karena media tidak sesuai dengan karakteristik siswa, kurang menariknya media dan banyak sebab yang lain.

Berdasarkan hasil observasi yang dilakukan di SMKN 1 Sakra khususnya pada mata pelajaran simulasi digital dapat dilihat bahwa pemanfaatan media pembelajaran oleh guru masih kurang, media pembelajaran yang digunakan oleh guru kurang inovatif, media yang digunakan oleh guru masih menggunakan presentasi powerpoin. Sedangkan berdasarkan wawancara yang dilakukan dengan guru mata pelajaran simulasi digital di SMKN 1 Sakra mengatakan bahwa motivasi siswa dalam pembelajaran masih kurang.

Salah satu cara untuk mengatasi permasalahan ini maka diperlukan media pembelajaran yang lebih menarik dan interaktif supaya pembelajaran tidak membosankan. Media yang akan digunakan yaitu media pembelajaran $C D$ tutorial interakif. Media pembelajaran $\mathrm{CD}$ tutorial interaktif ini akan memberikan proses pembelajaran yang lebih menarik dan kreatif. Dimana Media Pembelajaran adalah media yang membawa pesan-pesan atau informasi yang bertujuan intruksional atau mengandung maksud-maksud pengajaran Arsyad (Rusman, 2011:4). Sedangkan CD Tutorial interaktif adalah program yang dibuat untuk menyampaikan informasi penting dimana user dapat menggunakan program tersebut Media pembelajaran CD tutorial interaktif yang dikembangkan menggunkan program aplikasi Adobe Flash Cs6.

Berdasarkan uraian di atas peneliti tertarik melakukan penelitian dengan mengembangkan media pembelajaran $\mathrm{CD}$ tutorial interaktif pada mata pelajaran simulasi digital pada kelas $\mathrm{X}$ di SMKN 1 sakra.

\section{TINJAUAN PUSTAKA}

Rusman (2012: 160) dan Aqib (dalam prasetyo, 2015) menyatakan bahwa media pembelajaran adalah segala sesuatu yang digunakan untuk menyalurkan pesan serta dapat merangsang pikiran, perasaan, perhatian, dan kemauan siswa belajar sehingga dapat mendorong terjadinya proses belajar yang disengaja, bertujuan, dan terkendali. Oleh karena itu, media pembelajaran merupakan suatu teknologi pembawa pesan yang dapat digunakan untuk keperluan pembelajaran dan sarana fisik untuk menyampaikan materi pelajaran. Media pembelajaran merupakan sarana komunikasi dalam bentuk cetak maupun audio termasuk teknologi perangkat keras. 
Media pembelajaran CD tutorial interaktif mempunyai dua bagian yakni penggunaan CD multimedia interaktif dan menggunakan video interaktif. CD multimedia interaktif merupakan media pengajaran dan pembelajaran yang sangat menarik dan paling peraktis penyajiannya dengan memanfaatkan komputer. Media komputer dengan menggunakan CD ini bersifat interaktif, yang dapat menerima respon balik dari anak didik sehingga mereka secara langsung belajar dan memahami materi pengajaran yang telah disediakan. Dengan cara yang demikian, media pembelajaran ini akan cukup efektif meningkatkan hasil belajar siswa. Media ini bersifat inteaktif dan berbentuk multimedia yang memiliki animasi, video, teks, dan grafis. Sehingga, media ini dinamakan CD multimedia interaktif (Indriana, 2011: 116).

Sedangkan CD tutorial bagian dari CD multimedia interaktif, sehingga CD tutorial fungsinya sama dengan CD multimedia interaktif. Video juga bisa dimasukkan sebagai media pembelajaran. Namun, dengan CD multimedia interaktif adalah video ini hanya bersifat interaktif-tutorial, yang mampu membimbing siswa untuk memahami sebuah materi melalui aspek visul saja, tidak multimedia secara penuh. Meskipun demikian, media ini juga sangat membantu dalam proses pembelajaran siswa. Misalnya, siswa dapat mengetahui cara penyerbukan bunga, cara membuat okulasi, proses pembelahan sel, proses terbentuknya awan dan hujan, proses metabolism tubuh, dan lain semacamnya (Indiana, 2011: 120-121).

Ilham dkk (2013: 2) Mata pelajaran Simulasi Digital adalah mata pelajaran yang membekali peserta didik agar dapat mengomunikasikan gagasan atau konsep melalui media digital. Dalam proses pembelajaran, peserta didik dapat mengomunikasikan gagasan atau konsep yang dikemukakan orang lain dan mewujudkannya melalui presentasi digital, dengan tujuan untuk menguasai teknik mengomunikasikan gagasan atau konsep. Media digital yang dimanfaatkan untuk mengomunikasikan gagasan atau konsep, dipilih dari yang telah tersedia secara luas melalui aplikasi atau layanan dengan menggunakan peralatan elektronika atau peralatan teknologi informasi dan komunikasi yang ada.

\section{METODE}

Jenis penelitian yang digunakan pada penelitian ini adalah penelitian pengembangan $\mathrm{R} \& \mathrm{D}$ (Reseach and Development). Penelitian ini mengembangkan produk berupa Media Pembelajaran CD Tutorial Interaktif Pada Mata Pelajaran Simulasi Digital, sehingga produk dapat dikembangkan sesuai tujuan yang telah ditentukan. Model yg digunakan untuk mengembangkan produk pada penelitian ini akan menggunakan model Sugiyono (2011: 298) yang terdiri dari 10 tahapan sebagai berikut: 1) Potensi dan masalah, (2) Pengumpulan data, (3) Desain produk, (4) Validasi desain, (5) Revisi desain, (6) Uji coba produk, (7) Revisi produk, (8) Uji coba pemakaian, dan (9) Revisi produk, (10) produksi massal.

Produk yang akan dibuat merupakan perangkat keras media pembelajaran CD Tutorial Interaktif. Sebagai dasar pembuatannya, dengan menggunakan program aplikasi Adobe Flash Cs6.maka perangkat keras dapat dikembangkan dengan mudah, baik secara individu maupun berkelompok. Fitur akan disesuaikan dengan kebutuhan sekolah, fitur utama yang akan dibuat pada media pembelajaran CD Tutorial Interaktif ini antara lain peserta didik akan lebih aktif, terampil, dan kreatif sehingga mengurangi tingkat kebosanan.

Penelitian ini dilaksanakan pada siswa kelas X TKJ. Waktu penelitian dilaksanakan pada bulan Agustus sampai dengan bulan Juni 2018. Banyak siswa yang digunakan dalam penelitian ini adalah 20 siswa kelas X TKJ. Variabel dalam penelitian ini terdiri dari (Independen Variabel) dan variabel terikat (dependent variabel).Variabel bebas dalam penelitian ini adalah CD Tutorial Sedangkan variabel terikat dalam penelitian ini adalah simulasi digital dankelas X TKJ. 


\section{HASIL DAN PEMBAHASAN}

\section{Hasil Penelitian}

a. Pengembangan Media CD Tutorial Interaktif

Tampilan Utama

Halaman utama merupakan halaman yang pertama kali muncul saat pengguna membuka aplikasi media pembelajaran CD tutorial interaktif, pada halaman ini ada tombol Home yang berfungsi mengarahkan pengguna masuk ke halaman Home. Pada halaman Home merupakan halaman utama yang terdiri dari 5 macam tombol perintah yaitu tombol $\mathrm{KI} / \mathrm{KD}$, tombol Materi, tombol Galeri, tombol Evaluasi dan tombol Profil.

Berikut hasil screnshoot dari halaman home.
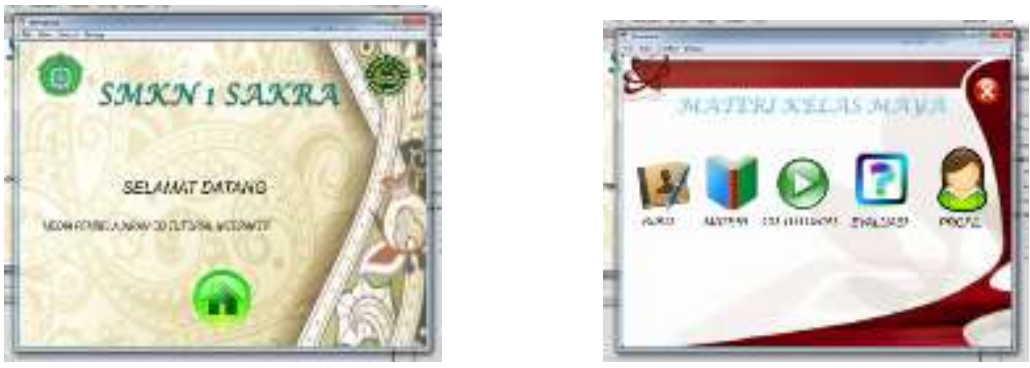

Gambar 1 Halaman Utama dan Halaman Home

Halaman KI/KD

Halaman KI/KD berisi $\mathrm{KI} / \mathrm{KD}$ tentang materi pembelajaran kelas maya. Berikut hasil screnshoot dari halaman $\mathrm{KI} / \mathrm{KD}$.
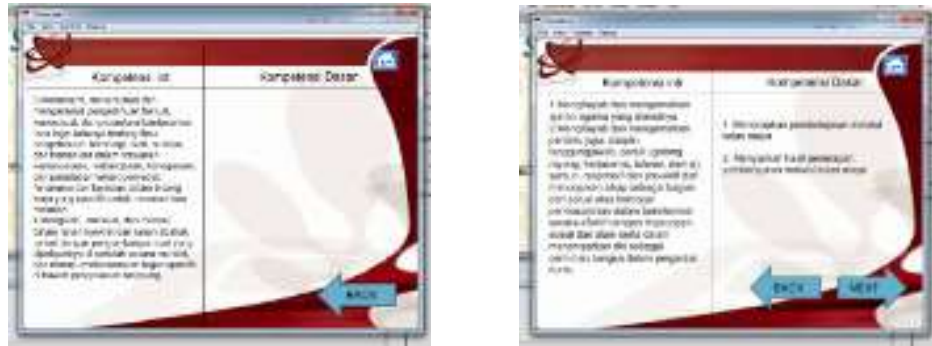

Gambar 2 Halaman KI/KD

Halaman Materi

Saat pengguna memilih halaman materi maka pengguna akan langsung di arahkan ke dalam materi dimana ada tiga sub pokok materi yang di tampilkan yaitu Materi Pembuatan akun siswa, pengaturan akun siswa dan pengaturan profil siswa. Berikut hasil screnshoot dari halaman Materi.

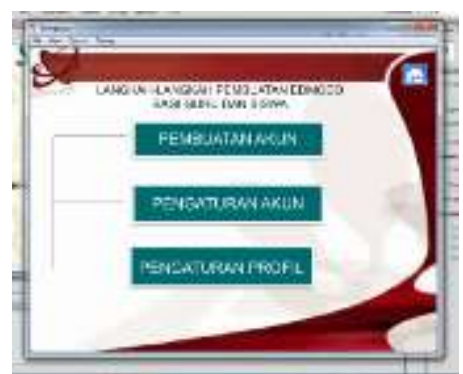

Gambar 3 Halaman Materi

EDUMATIC: Jurnal Pendidikan Informatika | 69 


\section{Halaman Video Tutorial}

Pada halaman ini pengguna akan diarahkan pada 3 pilihan judul pembelajaran kelas maya diantaranya cara pembuatan akun siswa(video 1), pengaturan akun siswa(video 2), dan pengaturan profil siswa(video 3), saat pengguna menekan salah satu tombol peritah maka akan langsung diarahkan ke halaman tampilan video tutorial. Berikut hasil screnshoot dari halaman Video tutorial.
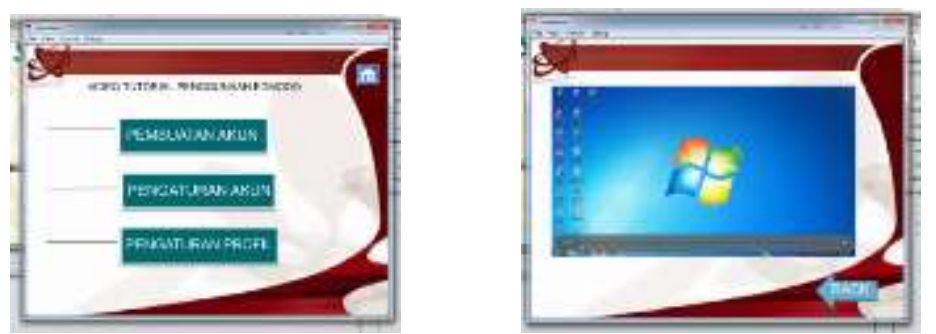

Gambar 4 Halaman Video Tutorial

Halaman Evaluasi

Halaman evaluasi adalah contoh soal berupa pilihan ganda terkait dengan materi yang disajikan sebelumnya dihalaman materi. Berikut hasil screnshoot dari halaman evaluasi.

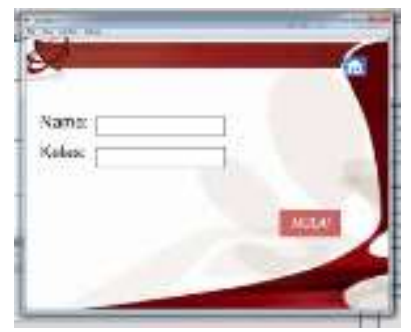

Gambar 5 Halaman Evaluasi

Halaman Profil

Halaman profil berisi biodata pengembang media pembelajaran CD tutorial interaktif. Berikut hasil screnshoot dari halaman profil.

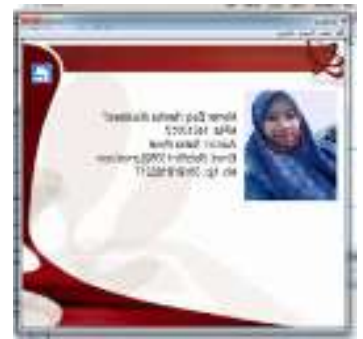

Tampilan Keluar

Gambar 6 Halaman Profil

Pada halaman keluar ini pengguna disediakan tombol ya dan tidak. Jika pengguna mengklik ya maka akan keluar dari media tersebut, sedangkan jika pengguna mengklik tidak maka akan kembali ketampilan menu. Berikut hasil screnshoot dari halaman keluar. 


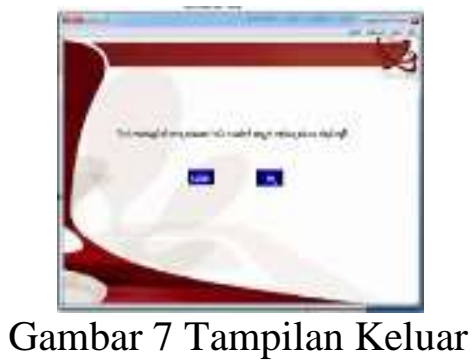

\section{b. Uji Coba Produk}

Hasil kelayakan sangat diperlukan untuk mengevaluasi media pembelajaran yang di kembangkan. Ahli media dan materi yang dipilih adalah yang dipilih Ahmad Fathoni, S.Kom.,M.Pd dan Yosi Nurkholisho,M.Pd Dosen Fakultas FKIP Universitas Hamzanwadi. Ahli materi I yang dipilih adalah bapak Muhammad, S. Kom guru SMKN 1 Sakra dan ahli materi II yang dipilih dalam penelitian ini adalah Ibu Baiq Hariati, S. Kom guru SMK AlMukhtary NW Bungtang. Berikut adalah tabel hasil kelayakan ahli media dan materi.

\section{Tabel 2 Hasil Kelayakan}

\begin{tabular}{lccc}
\hline No & Validator & $\begin{array}{c}\text { Persentase } \\
\text { \% }\end{array}$ & $\begin{array}{c}\text { Kriteria } \\
\text { kelayakan }\end{array}$ \\
\hline 1. & Ahli media & 92 & SangatLayak \\
\hline 2. & Ahlimateri & 91 & SangatLayak \\
\hline
\end{tabular}

Data hasil kelayakan media pembelajaran CD tutorial diperoleh persentase penilaian untuk ahli media adalah sebesar 92\% dengan kategori sangat layak dan begitu juga untuk ahli materi adalah sebesar $91 \%$ dengan kategori sangat layak.

\section{c. Respon Siswa}

Data hasil respon siswa diberikan kepada 20 siswa kelas $\mathrm{X}$ saat pelaksanaan pembelajaran simulasi digital dengan menggunakan media pembelajaran CD tutorial. Berikut adalah tabel hasil respon siswa terhadap media pembelajaran tersebut.

Tabel 3 Data Hasil Respon Siswa

\begin{tabular}{clc}
\hline No & \multicolumn{1}{c}{ Aspek } & $\begin{array}{c}\text { Rata-rata } \\
\text { Presentase }\end{array}$ \\
\hline 1 & Tampilan desain media & $88 \%$ \\
2 & Penyajian media pembelajaran & $90 \%$ \\
3 & Aspek keterbacaan dengan manfaat & $92 \%$ \\
\hline \multicolumn{2}{c}{ Total Presentase Nilai Respon Siswa } & $\mathbf{9 0 \%}$ \\
\hline
\end{tabular}

\section{Pembahasan}

\section{Pengembangan Media Pembelajaran}

Pengembangan media pembelajaran $\mathrm{CD}$ tutorial interaktif menggunakan model penelitian dan pengembangan atau Research and Development $(R \& D)$ ini menggunakan model penelitian sugiyono dengan langkah-langkah pelaksanaan penelitian dan pengembangan sebanyak 10 tahapan, yaitu: potensi dan masalah, pengumpulan data, desain produk, validasi desain, revisi desain, uji coba produk, revisi produk, uji coba pemakaian, revisi produk, dan produksi masal. Media pembelajaran yang dikembangkan berisi tampilan awal, tampilan masuk, menu, KI/KD, materi, galeri, evaluasi, profil, dan tampilan keluar. 


\section{Kelayakan media}

Kelayakan media pembelajaran CD Tutorial pada mata pelajaran simulasi digital pada kelas X di SMKN 1 Sakra didapatkan melalui validasi produk oleh ahli materi dan ahli media terhadap media pembelajaran CD Tutorial. Validasi produk adalah tahap penilaian media pembelajaran oleh ahli (ahli media dan materi, dimana ahli tersebut terdiri dari 2 Dosen ahli media, 2 Guru ahli materi). Proses validasi ahli materi dan media menggunakan angket.

Validasi oleh ahli media mencakup 3 aspek yang dibagi dalam beberapa indikator. Aspek-aspek tersebut adalah aspek desain media pembelajaran CD tutorial interaktif, aspek navigasi.dan pemrograman. Berdasarkan hasil analisa data hasil Persentase dari ketiga aspek ahli media tersebut didapatkan nilai Persentase kelayakan total dari ahli media sebesar 92\%, hasil tersebut apabila dipresentasikan menjadi sebuah keterangan maka didapatkan kriteria yang Sangat Layak untuk digunakan. Meskipun dengan hasil yang begitu memuaskan namun media pembelajaran ini masih perlu perbaikan-perbaikan, perbaikan tersebut berdasar pada saran dan komentar dari ahli media.

Validasi oleh ahli materi mencakup tiga aspek yang dibagi dalam beberapa indikator. Aspek-aspek tersebut adalah aspek tujuan Pembelajaran dengan materi, aspek keterbacaan dengan penyajian, dan bahasa. Berdasarkan hasil analisa data, pada ketiga aspek tersebut didapatkan nilai Persentase kelayakan total dari ahli materi sebesar 91\%, hasil tersebut apabila dipresentasikan menjadi sebuah keterangan maka didapatkan kriteria yang Sangat Layak untuk digunakan dari segi isi materi media pembelajaran yang dikembangkan. Meskipun dengan hasil yang begitu memuaskan namun media pembelajaran ini masih perlu perbaikan-perbaikan, perbaikan tersebut berdasar pada saran dan komentar dari ahli materi.

\section{Respon Siswa terhadap media}

Respon siswa mencakup tiga aspek yakni tampilan desain media, penyajian media pembelajaran dan keterbacaan dengan manfaat. Oleh karena itu, dalam aspek tampilan desain media hasil yang didapatkan adalah sebesar $88 \%$, sedangkan aspek penyajian media pembelajaran hasil yang didapatkan adalah $90 \%$, dan aspek keterbacaan dengan manfaat hasil yang didapatkan adalah sebesar $92 \%$. Berdasarkan persentase rata-rata respon siswa terhadap media CD tutorial interaktif sebesar 90\%, sehingga dikatakan masuk dalam kategori persentase Sangat Baik untuk digunakan pada mata pelajaran simulasi digital.

\section{SIMPULAN}

Pengembangan media pembelajaran CD tutorial interaktif pada mata pelajaran simulasi digital kelas X TKJ di SMKN 1 Sakra menghasilkan media pembelajaran yang dberisi halaman tampilan awal, tampilan masuk, menu, KI/KD, materi, video tutorial, evaluasi, profil dan tampilan keluar. Pengembangan media pembelajaran ini dibuat dengan menggunakan program aplikasi adobe flash CS 6 . Hasil uji kelayakan ahli media memberikan kriteria sangat layak (92\%), sedangkan hasil kelayakan ahli materi memberikan kriteria sangat layak $(91 \%)$. Sementara itu, hasil respon siswa terhadap produk yang telah dikembangkan adalah termasuk dalam kategori sangat baik (90\%).

\section{REFERENSI}

Diana, I. (2011). Ragam Alat Bantu Media Pembelajaran. Yogyakarta: Diva press.

Ilham, Dkk. (2013). Simulasi Digital Jlid 1. Jakarta: Kementrian Pendidikan dan Budaya. 
Heri, Prasetyo \& Agung. (2015). Pengembangan Media Pembelajaran Interaktif Berbasis CAI (Computer Assisted Instruction) Pada Mata Pelajaran Teknik Elektronik Dasar Kelas X Di SMKN 1 Nganjuk. Pendidikan Teknik Elektro , 4 (1), 103-108.

Aria, Pramudito \& Gagne. (2013). Pengembangan Media Video Tutorial Pada Mata Pelajaran Kompetensi Kejuruan Standar Kompetensi Melakukan Pekerjaan Dengan Mesin Bubut Di SMK Muhammadiyah 1 Playen. Pendidikan Teknik Mesin , 3 (1), 1-12.

Rusman. (2012). Belajar dan Pembelajaran Berbasis Komputer Mengembangkan Profesionalisme Guru Abad 21. Bandung: Alfabeta.

Arikunto, S. (2012). Dasar-dasar Evaluasi Pendidikan. Jakarta: Bumi Aksara.

Sugiyono. (2011). Metode Penelitian Kuantitatif Kualitatif dan R\& D. Bandung: Alfabeta.

Wijaya, I. (2017). Perancangaan dan Pembuatan MediaPembelajaaraan CD Interaktif Berbasis Maacromedia Direcor MX Mata Pelajaran Pemrograman Web Dinamis. Pendidikan dan Teknologi Informasi , 4 (2), 207-214.

Wirasasmita R.H., \& Yupi. (2015). Pengembangan Media Pembelajaran Video Tutorial Interaktif Menggunakan Aplikasi Camtasia Studio dan Macromedia Flash. jurnal Education , 10 (2), 262-279. 